\title{
Effects of glyphosate-resistant crop cultivation on soil and water quality
}

\begin{abstract}
Antonio L. Cerdeira ${ }^{1, *}$ and Stephen O. Duke²
${ }^{1}$ Brazilian Department of Agriculture; Agricultural Research Service; EMBRAPA/Environment; Jaguariuna, Sao Paulo Brazil; ${ }^{2}$ United States Department of Agriculture; Agricultural Research Service; Natural Products Utilization Research Unit; University, MI USA
\end{abstract}

Key words: glyphosate, soil, water, environment, herbicide-resistant crop

Abbreviations: AMPA, aminomethylphosphonate; EPSPS, 5-enolpyruvyl-shikimate-3-phosphate synthase; GR, glyphosate resistant; GRC, glyphosate-resistant crops; HRC, herbicide-resistant crops

Transgenic glyphosate-resistant crops (GRCs) have been commercialized and grown extensively in the Western Hemisphere and, to a lesser extent, elsewhere. GRCs have generally become dominant in those countries where they have been approved for growing. Potential effects of glyphosate on soil and water are minimal, compared to the effects of the herbicides that are replaced when GRCs are adopted. Perhaps the most important indirect effect is that GRCs promote the adoption of reduced- or no-tillage agriculture, resulting in a significant reduction in soil erosion and water contamination. Glyphosate and its degradation product, aminomethylphosphonate (AMPA), residues are not usually detected in high levels in ground or surface water in areas where glyphosate is used extensively. Furthermore, both glyphosate and AMPA are considered to be much more toxicologically and environmentally benign than most of the herbicides replaced by glyphosate. no review focused on the effects of GRC cultivation on soil and water quality.

The vast majority of HRCs used in agriculture are GRCs. So, in this review, we focus on the potential effects of GRCs on soil and water quality. Different formulations of glyphosate will not be discussed, as the actual composition of additives to these products, other than the active herbicide ingredients, are generally trade secrets and can vary between geographical regions and with time, even with products of the same trade name. The potential environmental impact of a technology is often geography and/ or time dependent. Thus, extrapolation of the results and conclusions of studies to all situations is impossible. Generalizations from reported studies may not cover every situation. For a realistic assessment of risk, we will contrast certain risks of GRCs with the risks that the GRCs displace.

\section{Glyphosate-Resistant Crops}

\section{Introduction}

Herbicide resistance and insect resistance are the only two types of transgene-imparted traits for crops that have so far had a marked effect on agriculture. ${ }^{1}$ The term 'herbicide-resistant crop' (HRC) describes crops made resistant to herbicides by transgene technology. HRCs have been the subject of numerous previous reviews, ${ }^{2-15}$ two books $s^{16,17}$ and special issues of the journal Pest Management Science in 2005 and 2008, the latter issue covering only glyphosate-resistant crops (GRCs). A review has covered agronomic and environmental aspects of HRCs. ${ }^{18}$ Other reviewers have discussed the environmental impacts of all transgenic crops, with coverage of HRCs. ${ }^{19,20}$ Lutman et al. ${ }^{21}$ and Kuiper et al. ${ }^{22}$ published brief reviews of environmental consequences of growing HRCs. Other reviews have focused entirely on GRCs. ${ }^{3,4}$ Reviews on the fate of glyphosate in soil and water ${ }^{23}$ and the influence of GRCs on soil ${ }^{24}$ are available, but there is

*Correspondence to: Antonio L. Cerdeira; Email: cerdeira@cnpma.embrapa.br Submitted: 05/07/09; Revised: 06/24/09; Accepted: 07/01/09

Previously published online:

www.landesbioscience.com/journals/gmcrops/article/9404
Glyphosate [ $N$-(phosphonomethyl) glycine] is a highly effective, non-selective herbicide. It is considered to be one of the most toxicologically benign pesticides. ${ }^{25}$ Prior to introduction of GRCs, glyphosate was used in non-crop situations, before planting the crop, or with specialized application equipment to avoid contact with the crop or other desirable vegetation. ${ }^{26-28}$ It inhibits the shikimate pathway by inhibiting the enzyme 5-enolpyruvylshikimate-3-phosphate synthase (EPSPS). This results in reduced aromatic amino acids and deregulation of the pathway. The latter effect causes massive flow of carbon into the shikimate pathway, with accumulation of high levels of shikimic acid and its derivatives. Glyphosate is particularly effective because most plants metabolically degrade it very slowly or not at all, and it translocates well to metabolically active tissues such as meristems. Its relatively slow mode of action allows movement of the herbicide throughout the plant before symptoms occur. Glyphosate is only used as a post-emergence herbicide, as it has little or no activity in soil. Glyphosate is an anion and is sold as a salt with different cations (e.g. isopropyl amine, trimethylsulfonium, diammonium).

Most GRCs are produced using the $\mathrm{CP} 4$ gene of Agrobacterium sp. (now classified as Rhizobium sp.), found to encode a highly efficient, glyphosate-resistant EPSPS. Plants transformed with this gene are highly resistant (ca. 50x) to glyphosate. ${ }^{29}$ Glyphosate 


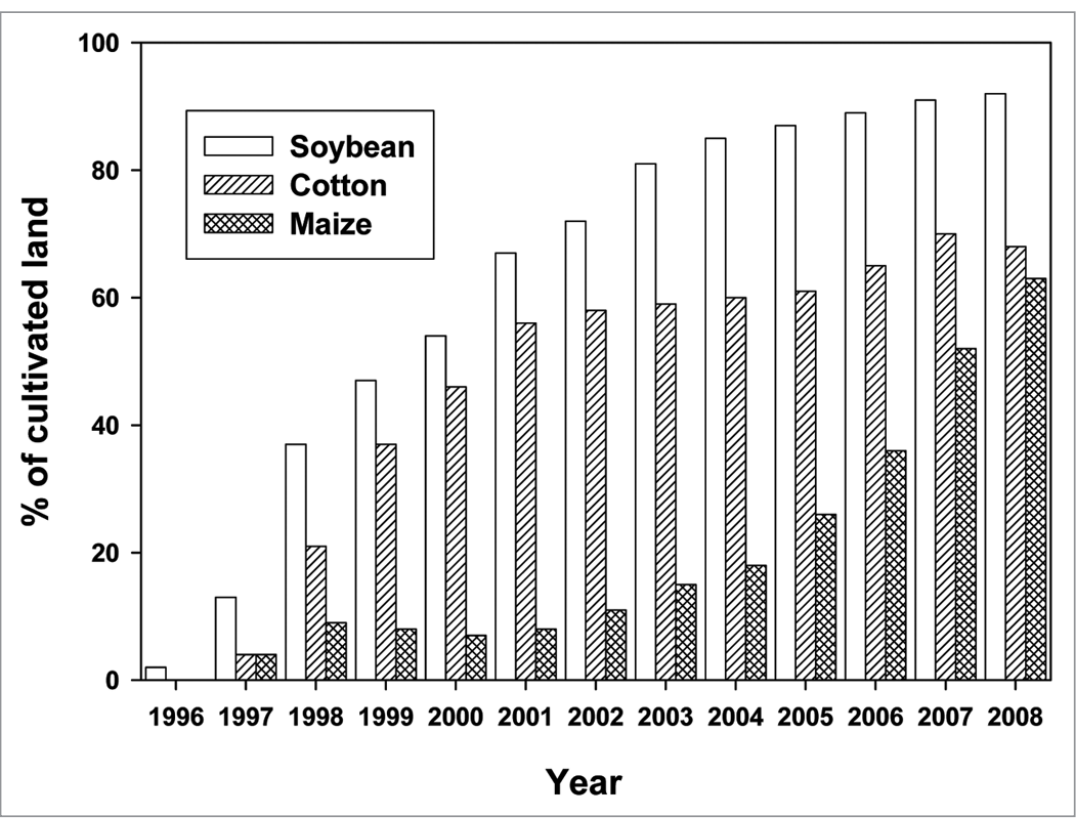

Figure I. Adoption of GR soybean, cotton and maize in the USA by year. For maize and cotton, the total includes crops with only the GR trait plus those with transgenes for both glyphosate resistance and $\mathrm{Bt}$ toxin. Data from USDA. ${ }^{32}$

Table I. Transgenic GRCs that have been or are now available to farmers (de-regulated) in North America

$\begin{array}{cc}\text { Crop } & \text { Year made available } \\ \text { Soybean } & 1996 \\ \text { Canola } & 1996 \\ \text { Cotton } & 1997 \\ \text { Maize } & 1998 \\ \text { Sugarbeet' }^{\prime} & 1999 \\ \text { Alfalfa }^{2} & 2005\end{array}$

'Never grown by farmers in 1999, withdrawn in 2004, but re-introduced in 2008. ${ }^{2}$ Re-regulated by court order in 2007. (Adapted from Duke and Cerdeira, 2005, ${ }^{9}$ and updated from the Information Systems for Biotechnology $\left.{ }^{31}\right)$.

oxidoreductase (GOX), encoded by a gene from the soil microbe Ochrobactrum anthropi, degrades glyphosate to glyoxylate, a ubiquitous and safe natural product, and aminomethylphosphonate (AMPA), also a toxicologically benign compound. ${ }^{25}$ This gene has been used along with the CP4 gene in GR canola. GR canola had an approximately 50 -fold level of resistance to glyphosate when compared to conventional canola. ${ }^{29} \mathrm{~A}$ multiple missense mutation in endogenous maize EPSPS produced by site-directed mutagenesis (GA21 gene) is utilized to generate commercial glyphosate resistance in some varieties of maize. ${ }^{30}$ All GRC varieties use the CP4 EPSPS gene, except for the GA21 maize varieties.

To date, GR soybean, cotton, canola, sugarbeet and maize are available to farmers of North America, ${ }^{9,31}$ (Table 1). The adoption rate of GR cotton, soybeans and maize in North America has been high ${ }^{32}$ (Fig. 1). This has been in large part because of the significantly reduced cost of excellent weed control obtained with the GRC/glyphosate package. ${ }^{33,34}$ Simplified and more flexible weed control also contributed to the rapid adoption. Approximately $62 \%$ of the canola acreage in the US was planted in GR varieties in 2005..$^{35}$ Adoption of GR soybeans was more rapid in Argentina than in the US ${ }^{36,37}$ Initially, the economic advantage was not as clear with GR maize, but after a lag phase adoption has increased rapidly to approach the level of adoption of cotton (Fig. 1).

Despite great success with other GRCs, GR sugarbeet was not grown by North American sugarbeet farmers after it was first deregulated, due to concerns about acceptance of sugar from transgenic plants by the confectionary and other prepared food industries. Similar and other concerns resulted in a decision by the company owning GR wheat technology not to ask for deregulation in $2004 .{ }^{38}$ GR sugarbeet was reintroduced in 2008, with an unprecedented adoption rate of about $60 \%$ for the initial year of availability and an anticipated $95 \%$ adoption in 2009 (personal communication, Thomas Schwarz, Beet Sugar Development Foundation). GR alfalfa was introduced and well accepted by farmers in 2005 , but deregulation was challenged in court by organic alfalfa growers in 2007, resulting in removal of the product from the market. There are no GRCs outside of the USA that are not available in the USA. ${ }^{39}$

\section{The Effects of HRCs on the Use of Herbicides}

Controversy about whether GRCs have increased herbicide use or not has been fueled by the assumption by some that increased amounts of chemical use equals increased environmental damage and toxicological risk. This assumption does not take into account the clear fact that the potential environmental damage and toxicological risk can vary by orders of magnitude between different herbicides. ${ }^{40}$ Thus, comparing herbicide use rates has relatively little bearing on potential environmental damage or toxicological risk to humans or other animals.

Some studies have claimed that the volume of herbicide use is greater with GRCs. ${ }^{41,42}$ However, others, such as Heimlich et al. ${ }^{43}$ have concluded that no significant change in the overall amount of herbicide has been observed with the adoption of GRCs in the USA. Indeed, USDA statistics showed little overall reduction in the volume of herbicides used in soybeans for the first 5 years after adoption of GR soybeans. ${ }^{44}$ There is no clear agreement on the impact of GRCs on the volume of herbicide use. ${ }^{45}$

Herbicide use patterns have changed dramatically in GRCs. For example, after introduction of in GR soybeans in the US, the use of herbicides other than glyphosate was reduced to only a small percent of what was used before. ${ }^{44}$ In the case of cotton, Werth et al. ${ }^{46}$ found that in Australia herbicide use patterns were altered by the adoption of GR varieties, with up to six times more glyphosate usage, but $21 \%$ fewer growers applied pre-emergence herbicides in GRC fields. Glyphosate was the most used active 
ingredient in 2001 (between 39 million and 41 million kilograms), displacing atrazine, which had been the most used active ingredient in agriculture for a number of years. ${ }^{47}$

Heimlich et al. ${ }^{43}$ pointed out that the adoption of GRCs resulted in the replacement of herbicides that are sometimes at least three times more toxic, and that persist nearly twice as long as glyphosate. Gardner and Nelson ${ }^{40}$ found similar effects of adoption of GRCs. In conventional tillage systems, they estimated the number of $\mathrm{LD}_{50}$ doses of herbicides applied per hectare to be reduced 17-98\%, depending on the GRC.

Herbicide use patterns and rates of use are not static with GRCs. The appearance of GR weeds, both natural and evolved, is leading farmers to increase dose rates and the number of applications of glyphosate, as well as to use other herbicides with GRCs. Current trends in herbicide use in US soybeans indicate that the volume of herbicides used may be going up. ${ }^{44}$ This trend is jeopardizing the initial toxicological risk reduction due to adoption of GRCs. ${ }^{40}$ Many strategies to stop or mitigate the evolution of and shifts to GR weeds have been proposed. ${ }^{4,48}$

\section{Effects on Soil}

Glyphosate has a moderate half-life in soils with an average value of approximately 47 days, reaching 174 days in some soils under some conditions. ${ }^{49,50}$ Glyphosate strongly adsorbs to soil particles and is rapidly degraded by soil microbes (reviewed by Duke $^{51}$ and Duke et al. ${ }^{27}$ ). It has little or no herbicidal activity after it reaches the soil, and it is degraded by many microbes to glyoxylate and AMPA. ${ }^{52}$ Other microbes can convert glyphosate to inorganic phosphate and sarcosine, and some can use glyphosate as both a carbon and phosphorus source. The two microbial pathways ${ }^{53}$ for mineralization of glyphosate in soil are shown in Figure 2. Glyphosate is rapidly degraded by soil microbes, even at high application rates, without adversely affecting overall microbial activity. ${ }^{54}$ Haney et al. ${ }^{54,55}$ found an increase in cumulative soil carbon mineralization with increasing glyphosate rate. The $\mathrm{CO}_{2}$ flush 2 days after application suggested that glyphosate was either readily and directly utilized by soil microbes or made other resources available.

In a study conducted for 5 years under continuous GR maize, ${ }^{24}$ soils maintained greater soil organic carbon and nitrogen as compared with continuous non-GR maize. The authors concluded that glyphosate use results in minor effects on soil properties, including microbial communities. They speculated that the enhanced organic carbon and plant residues in surface soils under conservation practices buffer potential effects of glyphosate on biological and chemical properties of soil.

Persistence in soil and effects on soil biota. Glyphosate is considered not to be a significant soil contaminant when used at recommended doses. It is applied in foliar sprays, so that its presence in soil is from direct interception of spray by the soil surface or from runoff or leaching of the herbicide and/or its breakdown products from vegetation. Glyphosate can also be translocated to roots from foliar tissues and exuded by the roots into the soil. ${ }^{56,57}$ The kinetics of dissipation and half-life in soil show that any disturbance on the ecosystem would be very transient. Mamy et al., ${ }^{58}$ comparing the fate of glyphosate in three soils with that of four herbicides (trifluralin, metazachlor, metamitron and sulcotrione) that were formerly used frequently on crops that have now been made glyphosate resistant, found that glyphosate had the shortest half-life, which varied with soil type, whereas trifluralin had the longest. At 140 days after herbicide applications, the amounts of glyphosate and its metabolite residues in soils were the lowest in two soils, but not in a third loamy sand with low $\mathrm{pH}$. The environmental advantage in using glyphosate due to its rapid degradation might be counterbalanced by accumulation of AMPA, as there have been few studies showing effects of AMPA on ecotoxicity to soil or aquatic organisms.

Araujo et al. ${ }^{52}$ found that after 32 days incubation with glyphosate, the number of actinomycetes and fungi had increased, while the number of bacteria was slightly reduced. They also detected the glyphosate metabolite AMPA, indicating glyphosate 


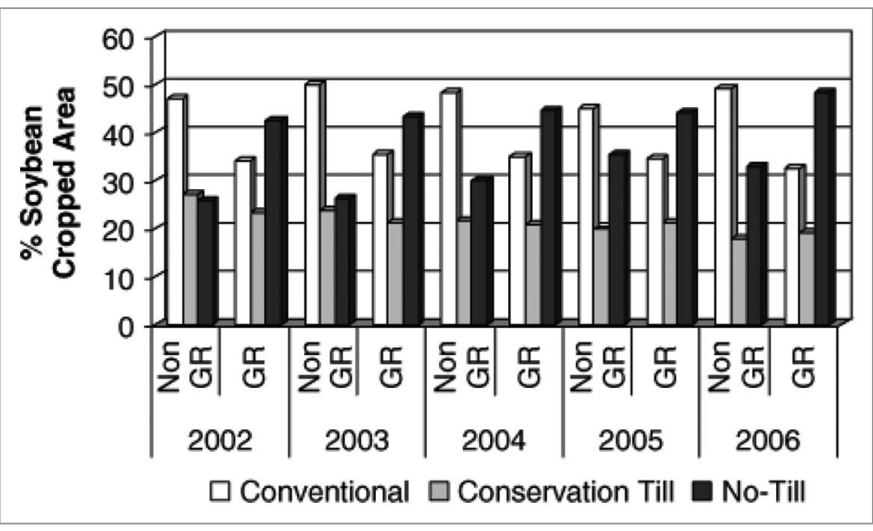

Figure 3. Comparison of US tillage practices in glyphosate-resistant (GR) and non-GR soybean from 2002-2006 as a percentage of hectares planted. From Dill et al. ${ }^{39} @ 2008$, Society of Chemical Industry. Reproduced with permission of John Wiley \& Sons Ltd. on behalf of the SCI.

degradation by soil microorganisms. Other studies ${ }^{54,55}$ have generated data strongly suggesting that glyphosate causes enhanced microbial activity directly. An increase in the carbon mineralization rate occurred the first day following glyphosate addition and continued for 14 days. Glyphosate appeared to be rapidly degraded by soil microbes regardless of soil type or organic matter content, even at high application rates, without adversely affecting microbial activity.

Studying the effects on bacterial density, Zabaloy et al. ${ }^{59}$ observed an early stimulation of substrate-induced respiration and aerobic heterotrophic bacteria. Overall, Busse et al. ${ }^{60}$ concluded that long-term, repeated applications of glyphosate had minimal effect on seasonal microbial characteristics despite substantial changes in vegetation composition and growth. Instead, variation in microbial characteristics was a function of time of year and site quality. Community size, activity and metabolic diversity generally were greatest in the spring and increased as temperature and moisture conditions improved, regardless of herbicide treatment. They also suggested that artificial media assays are of limited relevance in predicting glyphosate toxicity to soil organisms and that field rate applications of glyphosate should have little or no effect on soil microbial communities. Levesque and Rahe, ${ }^{61}$ also found no clear effect on soil microbial communities.

Glyphosate can be directly toxic to both soilborne bacterial and fungal plant pathogens with glyphosate-sensitive EPSPS. ${ }^{62,63}$ The relationship between glyphosate and Fusarium spp. has been studied more than other glyphosate/pathogen interactions. Kremer et al. ${ }^{64}$ examined exudates of hydroponically grown GR soybean at 16 days post-glyphosate application. They found with in vitro bioassays that glyphosate in the exudates stimulated growth of some rhizosphere fungi, possibly by providing a selective $\mathrm{C}$ and $\mathrm{N}$ source combined with the high levels of carbohydrates and amino acids associated with glyphosate treatment of the soybean plants. This promotes fungal populations that develop under glyphosate treatment of GR soybean, stimulating growth of selected Fusarium spp. from the soybean rhizosphere.
Krzysko-Lupicka and Sudol, ${ }^{65}$ determined that the dominating species of Fusarium were Fusarium solani H30, Fusarium solani $\mathrm{H} 50$ and Fusarium oxysporum $\mathrm{H} 80$ and that survival of Fusarium spp. in the soil environment was potentially dangerous to crops. In another study, Meriles et al. ${ }^{66}$ also found that in soil treated with a range of glyphosate concentrations, populations of Fusarium and Pythium species increased proportionally to the increment of glyphosate concentration, and no effect was found on Trichoderma spp. and Gliocladium spp. populations. In a recent review, Powell and Swanton ${ }^{67}$ concluded that there was still insufficient data to determine whether glyphosate application increases incidence of Fusarium spp. associated diseases in GR crops.

High doses of glyphosate in soil will reduce colonization of pepper (Capsicum annuum) plant roots with mycorrhizae. ${ }^{68}$ Whether effects were due to a direct effect on the mycorrhizae or to effects on the plant is not known. The doses of glyphosate used also inhibited growth of pepper. However, plants with mycorrhizae were more resistant to the growth-inhibiting effects of glyphosate. The authors concluded that mychorrhization might be useful in making plants more resistant to glyphosate in soil. The effects of glyphosate on mychorrhization in GRCs are unknown.

Effects of GRCs on tillage systems. Reduced or zero tillage agronomic systems have been facilitated by GRCs. These systems contribute to reductions in soil erosion from water and wind, fossil fuel use, air pollution from dust, loss of soil moisture, and soil compaction. ${ }^{69}$ Reduced tillage also improves soil structure, leading to reduced risk of runoff and pollution of surface waters with sediment, nutrients and pesticides. Loss of top soil due to tillage is perhaps the most environmentally destructive effect of agriculture. Even taking land out of its natural state for agriculture is more rapidly reversible than the loss of top soil, which, once lost, can take centuries or even millenia to return to its preagricultural natural state.

In a five-year period in the USA, during which the planting of GR soybeans increased from only a few percent to about $70 \%$ (Fig. 1), a survey by the American Soybean Association (2001) $)^{70}$ found that $53 \%$ of USA soybean farmers made an average of 1.8 fewer tillage passes per year through their soybean fields since GR soybeans were introduced. This translates to a savings of $\$ 385$ million per year in reduced tillage costs. A more recent study has also shown a dramatic increase in the adoption of no-tillage and reduced tillage management associated with the growing of GR soybeans (Fig. 3). ${ }^{39}$

Similarly, there has been a rise in no-tillage agriculture in soybeans in Argentina with the adoption of GR soybeans, where there is a loss of 10 tons of topsoil per hectare in soybeans produced with conventional tillage. ${ }^{37}$ Before GR cotton was introduced, essentially all cotton in the USA was grown with conventional tillage methods. Farmers in the USA growing GR cotton during 2002-2006 were much more likely to use reduced tillage and notillage practices than those planting conventional cotton. ${ }^{39}$

Use of GRCs has generally resulted in fewer herbicide applications, meaning fewer trips across the field with a tractor. This should result in less soil compaction; however, to our knowledge, the shift to no-tillage agriculture that many farmers using GRCs 
have made has not been studied in the context of soil compaction, nor have soil compaction factors been related to soil microbial activity or shifts in weed species. ${ }^{39}$

\section{Surface and Groundwater Quality}

In a recent review, Borggaard et al..$^{23}$ concluded that the risk of ground and surface water pollution by glyphosate seems limited because of sorption onto variable-charge soil minerals (e.g., aluminum and iron oxides) and because of microbial degradation. Although sorption and degradation are affected by many factors that might be expected to affect glyphosate mobility in soils, glyphosate leaching seems mainly determined by soil structure and rainfall. Glyphosate in drainage water runs into surface waters but not necessarily to groundwater because it may be sorbed and degraded in deeper soil layers before reaching the groundwater. According to the World Health Organization (WHO) ${ }^{71}$ guidelines, under usual conditions, the presence of glyphosate and AMPA in drinking-water does not represent a hazard to human health. An extensive review conducted by Vereecken, ${ }^{72}$ about the mobility and leaching of glyphosate concluded that in the USA and Europe there was a low occurrence of glyphosate in groundwater.

Klier et al., ${ }^{73}$ studying glyphosate behavior based on the pesticide transport model LEACHP and the model PLANTX to simulate the pesticide uptake by plants implemented in the modular modeling system EXPERT-N, concluded that glyphosate transport measurements and the mathematical modeling results indicate that, due to the high sorption of glyphosate to the soil matrix and the high microbial capacities for glyphosate degradation, soil leaching risks can be considered to be low. On the other hand, Mamy et al. ${ }^{74}$ found that the main metabolite of glyphosate, AMPA, was more persistent than glyphosate and because of the detection of AMPA in the deep soil layer, the replacement of both trifluralin and metazachlor due to glyphosate resistant oilseed rape might not contribute to decreasing environmental contamination by herbicides. But contamination does not equal toxicological hazard. They also concluded that predictions of the pesticide root zone model (PRZM) underestimated the dissipation rate of glyphosate and the formation of AMPA in the field.

Laitinen et al. ${ }^{57}$ suggested that plant translocation of glyphosate to roots should be included both in leaching assessments and pesticide fate models. After glyphosate fate was simulated with the PEARL 3.0 model, the observed and simulated glyphosate residues in soil after canopy applications did not correlate, highlighting the importance of the translocation process in glyphosate fate in soil. Their studies indicated that some soil glyphosate residues must originate from exudation from plant roots, and that the translocation process should be included both in leaching assessments and pesticide fate models.

Scorza et al..$^{75}$ using the PEARL model to establish a ranking considering the main pesticides and their potential to contaminate groundwater in Brazil, evaluated 4,374 agronomic prescriptions used in the Dourados river watershed and concluded that the most used pesticides on the watershed area were glyphosate followed by 2,4-D, fipronil, methamidophos, imazaquin, parathion-Me, trifluralin and atrazine. Although glyphosate scored high in the amount used, their simulations revealed that the pesticides with the highest potential of groundwater contamination when used at the levels were bentazon, imazethapyr, fomesafen, 2,4-D, methamidophos, imazaquin, followed by the less used thiodicarb, and monocrotophos.

Long-term studies conducted in Canada with the herbicides glyphosate, dicamba, 2,4-D, bromoxynil, methylchlorophenoxyacetic acid (MCPA), diclofop and triallate showed no residues of glyphosate in groundwater. ${ }^{76}$ Various studies have shown that glyphosate contaminates surface water less than several alternative herbicides (summarized by Carpenter et al. ${ }^{19}$ ). Once in surface water, it dissipates more rapidly than most other herbicides. In the intensely farmed maize-growing regions of the midwestern USA, surface waters have often been contaminated by herbicides, principally as a result of rainfall runoff occurring shortly after application of these to maize and other crops. ${ }^{50} \mathrm{~A}$ model was used to predict maize herbicide concentrations in the reservoirs as a function of herbicide properties comparing broadcast surface pre-plant atrazine and alachlor applications with glyphosate or glufosinate post-emergent herbicides with both GR and glufosinate-resistant maize. ${ }^{50}$ Because of greater soil sorptivity, glyphosate loads in runoff were generally one-fifth to one-tenth those of atrazine and alachlor, indicating that the replacement of pre-emergent maize herbicides with glyphosate would dramatically reduce herbicide concentrations in watersheds. Even if glyphosate does find its way into watersheds, it is considered one of the safest pesticides to aquatic systems. Indeed, glyphosate is one of the few herbicides deemed safe enough for approved use in aquatic environments for vegetation emerging from water (e.g., cattails) or growing on banks of water systems.

Zablotowicz et al. $^{77}$ found that there was an association of reduced herbicide contamination of surface water with the adoption of GR cotton and soybeans in the Missisippi Delta. A more recent study by Shipitalo et al. $^{78}$ found in a multi-year study of GR soybeans grown in no-tillage or tilled conditions, that glyphosate runoff in surface water was below drinking water standard thresholds, whereas levels of certain other herbicides used as a comparison were not always below maximum allowable levels. AMPA levels in runoff water were also low.

In a comprehensive survey of the US Geological Service, USGS, (1998), ${ }^{79}$ more than $95 \%$ of all samples collected from streams and rivers contained at least one pesticide, compared to about $50 \%$ for ground water. Glyphosate was not among them. Although this study was done before the widespread adoption of GRCs, glyphosate was widely used as both a preplant and postharvest herbicide, as well as a harvest aid. Other studies also found no glyphosate in ground water in the United States where glyphosate is applied on no-tillage cropping system $s^{80}$ and in Brazil in various cropping systems. ${ }^{81-85}$ Similar results were found for surface waters. ${ }^{86}$

Leaching of glyphosate and/or its metabolite AMPA was studied in a low-tillage field and a normal tillage field. ${ }^{80} \mathrm{~A}$ significant difference between the soil residual concentrations of AMPA was seen, with the higher concentration found where low-tillage had been practiced and where glyphosate had been used several times in the years before sampling soil. Spatial and temporal variations in concentrations of glyphosate and AMPA have been observed in pre-and post-application $45-\mathrm{cm}$ deep soil cores divided into 
Table 2. Parameters contributing to leaching potential and health concerns of the main herbicides used on the primary conventional crops in Paraná State, Brazil in 2000 compared to glyphosate

\begin{tabular}{|c|c|c|c|c|}
\hline Herbicides & $K_{\text {oc }}(\mathrm{ml} / \mathrm{g})$ & $\mathbf{T}_{1 / 2}$ (days) & GUS & $L_{50}(\mathrm{mg} / \mathrm{kg})^{\prime}$ \\
\hline Atrazine & 165 & 60 & $L$ & 3090 \\
\hline Metolachlor & 200 & 195 & $\mathrm{~L}$ & $1200-2780$ \\
\hline Imazetapyr & 22 & 75 & $\mathrm{~L}$ & $>5000$ \\
\hline Pendimethalin & 17200 & 44 & NL & 1050 \\
\hline Trifluralin & 7000 & 45 & $\mathrm{NL}$ & $>5000$ \\
\hline Dicamba & 2 & 14 & $\mathrm{~L}$ & $757-1707$ \\
\hline Acetochlor & 55 & 20 & $L$ & $|426-2| 48$ \\
\hline Cyanazine & 190 & 14 & IN & $182-332$ \\
\hline Chorminuron & 110 & 40 & $\mathrm{~L}$ & 4100 \\
\hline Glyphosate & 24000 & 47 & $\mathrm{NL}$ & $>5600$ \\
\hline
\end{tabular}

NL, Does not leach, IN, Intermediate, L, Leaches easily, $\mathrm{K}_{\circ \mathrm{c}}$, Adsorption coefficient $\left(\mathrm{mg} / \mathrm{g}^{-1}\right), \mathrm{T}_{1 / 2}$, Half-life. LD ${ }_{50}$, Lethal dose; 'Lethal dose data from Extoxnet. ${ }^{\text {I }}$ GUS, Ground-water Ubiquity Score (adapted from Inoue et al.). ${ }^{92}$

Table 3. Predicted relative ecological risks of herbicide active ingredients based on modeling

\begin{tabular}{|c|c|c|c|c|}
\hline Active ingredient & Application rate (g ai/ha) & Groundwater value (ppb) & $\mathbf{R R}^{\mathbf{b}}$ & Aerobic soil half-life (days) \\
\hline Glyphosate & 840 & 0.0005 & I & 2 \\
\hline 2,4-D & 560 & 0.005 & 10 & 5.5 \\
\hline Clodinafop & 67 & 0.00003 & 0.06 & 1 \\
\hline Clopyralid & 146 & 0.06 & 120 & 26 \\
\hline Flucarbazone & 34 & 0.2 & 400 & NA \\
\hline MCPA & I,457 & 0.26 & 520 & 25 \\
\hline Metsulfuron & 9 & 0.004 & 8 & 28 \\
\hline Thifensulfuron & 22 & 0.0001 & 0.2 & 6 \\
\hline Tribenuron & 16 & 0.00003 & 0.06 & 2 \\
\hline Trifluralin & 1,100 & 0.009 & 18 & 169 \\
\hline
\end{tabular}

${ }^{\mathrm{a}}$ Abbreviations: RR, relative risk; NA, not available; ${ }^{\mathrm{b} R \mathrm{R}:}$ Relative Risk compared with glyphosate, value in bold indicates greater risk relative to glyphosate. (Adapted from Peterson and Hulting, 2004, ${ }^{97}$ with permission). ${ }^{2}$

15-cm intervals. ${ }^{87}$ Simonsen et al., ${ }^{88}$ studying the fate of glyphosate and its byproduct AMPA in soil, found that both compounds were better extracted from soil when phosphate was used as an extraction agent, compared with pure water indicating that the risk of leaching of aged glyphosate and AMPA residues from soil is greater in phosphate-fertilized soil.

Degradation of pesticides in aquifers has been evaluated, and glyphosate was found to be degraded under both anaerobic and aerobic conditions, as opposed to some other herbicides such as MCPA and mecoprop. ${ }^{89}$ Certain pesticides were not degraded in water under aerobic or anaerobic conditions (dichlobenil, bentazon, isoproturon and metsulfuron-methyl). This could be important when using glyphosate on GRCs, if the herbicide leached sufficiently to reach ground water, which is a more anaerobic environment. Half-lives of glyphosate vary from 60 hours for ground water samples exposed to sunlight to 770 hours for those stored under dark conditions. ${ }^{90}$

Ground water contamination risks for a particular herbicide use should be evaluated in the context of where the herbicides are replaced. As shown in Table 2, in Brazil special attention should be given to atrazine. ${ }^{91,92}$ Atrazine was used in most acreage before GRC introduction. Atrazine is banned in Europe due to the water contamination potential. Wauchope ${ }^{93}$ has shown that atrazine has a high potential for groundwater contamination despite its moderate solubility, which explains the detection of the pesticide in concentrations that exceed the health advisory level in some wells in the United States located on irrigated lands. ${ }^{94}$ According to Shipitallo et al. ${ }^{78}$ replacing atrazine and 
alachlor with glyphosate can reduce the occurrence of dissolved herbicide concentrations in runoff exceeding drinking water standards.

Glyphosate is considered to have a low risk for leaching ${ }^{95}$ and has a low GUS (Ground-water Ubiquity Score) index (Table 2). ${ }^{4}$ The GUS index ${ }^{96}$ assesses the leachability of molecules and the possibility of finding these herbicides in groundwater. The index is based on two widely available herbicide properties: half-life in soil $\left(t_{1 / 2}{ }^{\text {soil }}\right)$ and partition coefficient between soil organic carbon and water $\left(K_{\mathrm{oc}}\right)$. It can be calculated by the equation:

$$
\text { GUS }=\log _{10}\left(t_{1 / 2}\right) \times\left[4-\log _{10}\left(\mathrm{~K}_{\mathrm{oc}}\right)\right]
$$

Aquatic biota. Peterson and Hulting ${ }^{97}$ compared the ecological risks of glyphosate used in GR wheat with those associated with 16 other herbicides used in spring wheat in the northern Great Plains of the USA. A Tier 1 quantitative risk assessment method was used. They evaluated, among other things, acute risk to aquatic vertebrates, aquatic invertebrates and aquatic plants, and also estimated groundwater exposure. They found less risk with glyphosate than with most other herbicides to aquatic plants and groundwater (Table 3 ).

As we mentioned earlier, glyphosate is less likely to pollute ground and surface waters than many of the herbicides that it replaces. A life-cycle assessment technique used to compare conventional sugarbeet agricultural practices with risks that might be expected if GR sugarbeet were grown suggested that growing this GRC would be less harmful to the ecology of water for the herbicide-resistant crop than for the conventional crop. ${ }^{98}$ These results suggest less impact of GRCs on aquatic vegetation than conventionally grown crops.

Glyphosate was also evaluated for ecological risk assessment, and it was found not to bioaccumulate, biomagnify or persist in an available form in the environment. ${ }^{99}$ This study also showed that the risk to aquatic organisms is negligible or small at application rates $<4 \mathrm{~kg} / \mathrm{ha}$ and only slightly greater at application rates of 8 $\mathrm{kg} / \mathrm{ha}$. Solomon et al. ${ }^{100}$ also found no significant effect on aquatic organisms of use of glyphosate as aerial spray in Colombia to eradicate illicit coca plantations. Analyses of surface waters in five watersheds showed that, on most occasions, glyphosate was not present at measurable concentrations. Similarly, studies with surface water and sediment with glyphosate have also shown that adsorption to the bottom sediments, microbial degradation, the persistence of glyphosate in freshwater pond and effect on fishes used in the in situ bioassays posed no serious hazard. ${ }^{101}$

\section{Conclusion}

Glyphosate/GRC weed management offers significant environmental and other benefits over the technologies that it replaces. ${ }^{11}$ We have provided an abbreviated survey of the potential impacts (risks and benefits) of GRCs on soil and water quality. Clearly, we and many of the authors who have written on this topic emphasize that risks and benefits of any GRC are very geography and time dependent. For example, increasing GR weeds in GRCs are changing how farmers use these crops, and in most cases reducing the environmental benefits of GRC systems. Glyphosate is more environmentally and toxicologically benign than many of the herbicides that it replaces. Its effects on soil and water are relatively small. Soil erosion caused by tillage results in long-term environmental damage. Being a broad-spectrum, foliarly applied herbicide, with little or no activity in soil, glyphosate is highly compatible with reduced- or no-tillage agriculture and has contributed to the adoption of these practices in the Western Hemisphere. This contribution to environmental quality by GRCs is perhaps the most significant one. Numerous regulatory tests of glyphosate and glyphosate products, using rigorous protocols meeting international standards, as well as product post-marketing surveillance, have failed to reveal any effects that could help substantiate any claims of adverse health and environmental outcomes. ${ }^{102}$

\section{References}

1. Gutterson N, Zhang JZ. Genomics applications to biotech traits: a revolution in progress? Curr Opin Plant Biol 2004; 7:226-30.

2. Cerdeira AL, Duke SO. The current status and environmental impacts of glyphosate-resistant crops: A review. J Environ Qual 2006; 35:1633-58.

3. Cerdeira AL, Duke SO. Environmental impacts of transgenic herbicide-resistant crops. CAB Reviews 2007; 2 .

4. Cerdeira AL, Gazziero DLP, Duke SO, Matallo MB, Spadotto CA. Review of potential environmental impacts of transgenic glyphosate-resistant soybean in Brazil. J Environ Sci Health B 2007; 42:539-49.

5. Dekker J, Duke SO. Herbicide-resistant field crops. Adv Agron 1995; 54:69-116.

6. Duke SO. Herbicide-resistant crops - their influence on weed science. J Weed Sci Technol 1998; 43:94-100.

7. Duke SO. Herbicide-resistant crops. In: Pimentel E, ed. Enyclopedia of Pest Management. New York NY, USA: Marcel Dekker 2002; 358-60.

8. Duke SO. Taking stock of herbicide-resistant crops ten years after introduction. Pest Manag Sci 2005; 61:211-8.
9. Duke SO, Cerdeira AL. Potential environmental impacts of herbicide-resistant crops. Collection of biosafety reviews. Volume 2. Trieste, Italy: International Centre for Genetic Engineering and Biotechnology 2005; 67-143.

10. Duke SO, Holt JS, Hess FD, Christy AL. HerbicideResistant Crops. Ames IA, USA: Council for Agricultural Science and Technology 1991; 24.

11. Duke SO, Powles SB. Glyphosate: a once-in-a-century herbicide. Pest Manag Sci 2008; 64:319-25.

12. Duke SO, Scheffler BE, Dayan FE, Dyer WE. Genetic engineering crops for improved weed management traits. Amer Chem Soc Symp Ser 2002; 829:52-66.

13. Gressel J. Transgenic herbicide-resistant cropsadvantages, drawbacks and failsafes. In: OksmanCaldentey KM, Barz WH, eds. Plant Biotechnology and Transgenic Plants. New York NY, USA: Marcel Dekker, Inc 2002; 596-633.

14. Hess FD, Duke SO. Genetic engineering in IPM: A case study: herbicide tolerance. In: Kennedy GG, Sutton TB, eds. Emerging Technologies for Integrated Pest Management: Concepts, Research and Implementation. St. Paul MN, USA: Amer. Phytopath. Soc. Press 2000; $126-40$
15. Warwick S, Miki B. Herbicide resistance. In: Pua E-C Douglas CJ, eds. Biotechnology in Agriculture and Forestry. Volume 54, Brassica. New York NY, USA: Springer 2004; 273-95.

16. Duke SO. Herbicide-Resistant Crops. Boca Raton FL, USA: CRC Press 1996; 420.

17. McClean GD, Evans G. Herbicide-Resistant Crops and Pastures in Australian Farming Systems. Parkes ACT, Australia: Bureau of Resource Sciences 1995; 294.

18. Schuette G, Stachow U, Werner A. Agronomic and environmental aspects of the cultivation of transgenic herbicide-resistant plants. Berlin, Germany: TexteFederal Environmental Agency (Umweltbundesamt) 2004; 111. http://www.umweltdaten.de/publikationen/fpdf-1/2636.pdf (accessed 2008).

19. Carpenter J, Felsot A, Goode T, Hammig M, Onstad D, Sankula S. Comparative Environmental Impacts of Biotechnology-Derived and Traditional Soybean, Corn and Cotton Crops. Ames IA, USA: Council for Agriculture Science and Technology 2002; 189.

20. Uzogara SG. The impact of genetic modification of human foods in the $21^{\text {st }}$ century: A review. Biotechnol Adv 2000; 18:179-206.

21. Lutman P, Berry K, Sweet J. The environmental and agronomic consequences of growing herbicide tolerant crops. Pestic Outlook 2000; 11:242-4. 
22. Kuiper HA, Kleter GA, Noordam MY. Risks of the release of transgenic herbicide-resistant plants with respect to humans, animals and the environment. Crop Prot 2000; 19:773-8.

23. Borggaard OK, Gimsing AL. Fate of glyphosate in soil and the possibility of leaching to ground and surface waters: a review. Pest Manag Sci 2008; 64:441-56.

24. Locke MA, Zablotowicz RM, Reddy KN. Integrating soil conservation practices and glyphosate-resistant crops: impacts on soil. Pest Manag Sci 2008; 64:457-69.

25. Williams GM, Kores R, Munro IC. Safety evaluation and risk assessment of the herbicide Roundoup and its active ingredient, glyphosate, for humans. Regul Toxicol Pharmacol 2000; 31:117-65.

26. Duke SO. Glyphosate. In: Kearney PC, Kaufmann DD, eds. Herbicides-Chemistry, Degradation and Mode of Action. Volume III. New York NY, USA: Marcel Dekker, Inc 1988; 1-70.

27. Duke SO, Baerson SR, Rimando AM. Herbicides: Glyphosate. In: Plimmer JR, Gammon DW, Ragsdale NN, eds. Encyclopedia of Agrochemicals. New York NY, USA: John Wiley \& Sons 2003. http://mrw. interscience.wiley.com/emrw/9780471263630/home/. accessed 2009.

28. Franz JE, Mao MK, Sikorski JA. Glyphosate: A Unique, Global Herbicide. Washigton DC, USA: American Chemical Society 1997; 688.

29. Nandula VK, Reddy KN, Rimando AM, Duke SO, Poston DH. Glyphosate-resistant and -susceptible soybean (Glycine max) and canola (Brassica napus) dose response and metabolism relationships with glyphosate. J Agr Food Chem 2007; 55:3540-5.

30. Lebrun M, Sailland A, Freyssinet G. Glyphosateresistant enolpyruvylshikimate phosphate synthase genes and glyphosate-resistant transgenic plants. Patent AN 1997:281006. France: Rhone Poulenc Agrochimie 1997; 26.

31. ISB. Information Systems for Biotechnology. Crops No Longer Regulated By USDA. http://www.nbiap.vt.edu/ cfdocs/biopetitions1.cfm. Accessed 2008.

32. United States Department of Agriculture. Adoption of Genetically Engineered Crops in the U.S. http://www. ers.usda.gov/Data/BiotechCrops/. Accessed 2009.

33. Gianessi LP. Economic and herbicide use impacts of glyphosate-resistant crops. Pest Manag Sci 2005; 61:241-5.

34. Gianessi LP. Economic impacts of glyphosate-resistant crops. Pest Manag Sci 2008; 64:346-52.

35. Sankula S. Quantification of the Impacts on US Agriculture of Biotechnology-Derived Crops Planted in 2005. http://bric.postech.ac.kr/trend/ biostat/2006/20061123_1.pdf. Accessed 2009.

36. Monjardino M, Pannell DJ, Powles SB. The economic value of glyphosate-resistant canola in the management of two widespread crop weeds in a western Australian farming system. Agr Syst 2005; 84:297-315.

37. Penna JA, Lema D. Adoption of herbicide tolerant soybeans in Argentina: An economic analysis. In: Kalaitzandonakes N, ed. Economic and Environmental Impacts of Agrotechology. New York NY, USA: Kluwer-Plenum Publishers 2003; 203-20.

38. Dill GM. Glyphosate-resistant crops: history, status and future. Pest Manag Sci 2005; 61:219-24.

39. Dill GM, CaJacob CA, Padgette SR. Glyphosateresistant crops: adoption, use and future considerations. Pest Manag Sci 2008; 64:326-31.

40. Gardner JG, Nelson GC. Herbicides, glyphosate resistance and acute mammalian toxicity: simulating an environmental effect of glyphosate-resistant weeds in the USA. Pest Manag Sci 2008; 64:470-8.

41. Benbrook CM. Troubled times amid commercial success for Roundup Ready soybeans. http://www mindfully.org/GE/GE2/RRS-Troubled-Benbrook.htm. Accessed 2008.

42. Benbrook CM. Genetically Engineered Crops and Pesticide Use in the United States: The First Nine Years. http://www.biotech-info.net/Full_version_first_nine. pdf. Accessed 2009.
43. Heimlich RE, Fernandez-Cornejo J, McBride W, Klotz-Ingram C, Jans S, Brooks N. Genetically engineered crops: Has adoption reduced pesticide use? Agri Outlook 2000; 13-7.

44. Bonny S. Genetically modified glyphosate-tolerant soybean in the USA: adoption factors, impacts and prospects. A review. Agron Sustain Dev 2008; 28:2132.

45. Kleter GA, Harris C, Stephenson G, Unsworth J. Comparison of herbicide regimes and the associated potential environmental effects of glyphosate-resistant crops versus what they replace in Europe. Pest Manag Sci 2008; 64:479-88.

46. Werth JA, Preston C, Roberts GN, Taylor IN. Weed management practices in glyphosate-tolerant and conventional cotton fields in Australia. Aust J Exp Agr 2006; 46:1177-83.

47. EPA. Environmental Protection Agency. 2000-2001 Pesticide Market Estimates: Usage. http://www.epa gov/oppbead $1 /$ pestsales/01 pestsales/usage2001_2. htm\#table3_6. Accessed 2009.

48. Powles SB. Evolved glyphosate-resistant weeds around the world: lessons to be learnt. Pest Manag Sci 2008; 64:360-5.

49. Vencill WK. Herbicide Handbook. $8^{\text {th }}$ Ed. Lawrence KS, USA: Weed Science Society of America 2002; 493

50. Wauchope RD, Estes TL, Allen R, Baker JL, Hornsby AG, Jones RL, et al. Predicted impact of transgenic, herbicidetolerant corn on drinking water quality in vulnerable watersheds of the mid-western USA. Pest Manag Sci 2002; 58:146-60.

51. Duke SO. Herbicide-resistant crops-their influence on weed science. J Weed Sci Technol 1988; 43:94-100.

52. Araújo ASF, Monteiro RTR, Abarkeli RB. Effect of glyphosate on the microbial activity of two Brazilian soils. Chemosphere 2003; 52:799-804.

53. Bui T, Hershberger D, Essenberg C. Glyphosate pathway map. http://umbbd.msi.umn.edu/gly/gly_image_ map.html. Accessed 2008. [ ]

54. Haney RL, Senseman SA, Hons FM. Effect of roundup ultra on microbial activity and biomass from selected soils. J Environ Qual 2002; 31:730-5.

55. Haney RL, Senseman SA, Hons FM, Zuberer DA. Effect of glyphosate on soil microbial activity and biomass. Weed Sci 2000; 48:89-93.

56. Coupland D, Caseley JC. Presence of ${ }^{14} \mathrm{C}$ activity in root exudates and guttation fluid from Agropyron repens treated with ${ }^{14} \mathrm{C}$-labeled glyphosate. New Phyto $1979 ; 83: 17-22$

57. Laitinen P, Ramo S, Siimes K. Glyphosate translocation from plants to soil—does this constitute a significant proportion of residues in soil? Plant Soil 2007 300:51-60.

58. Mamy L, Barriuso E, Gabrielle B. Environmental fate of herbicides trifluralin, metazachlor, metamitron and sulcotrione compared with that of glyphosate, a substitute broad spectrum herbicide for different glyphosateresistant crops. Pest Manag Sci 2005; 61:905-16.

59. Zabaloy MC, Garland JL, Gómez MA. An integrated approach to evaluate the impacts of the herbicides glyphosate, 2,4-D and metsulfuron-methyl on soil microbial communities in the Pampas region, Argentina. Appl Soil Ecol 2008; 40:1-12.

60. Busse MD, Ratcliff AW, Shestak CJ, Powers RF Glyphosate toxicity and the effects of long-term vegetation control on soil microbial communities. Soil Biol Biochem 2001; 33:1777-89.

61. Levesque CA, Rahe JE. Herbicide interactions with fungal root pathogens, with special reference to glyphosate. Annu Rev Phytopathol 1992; 30:579-602.

62. Duke SO, Wedge DE, Cerdeira AL, Matallo MB Interactions of synthetic herbicides with plant disease and microbial herbicides. In: Vurro M, Gressel J, eds. Novel Biotechnologies for Biocontrol Agent Enhancement and Management. Dordrecht, The Netherlands: Springer 2007; 277-96.
63. Sanyal D, Shrestha A. Direct effect of herbicides on plant pathogens and disease development in various cropping systems. Weed Sci 2008; 56:155-60.

64. Kremer RJ, Means NE, Kim S. Glyphosate affects soybean root exudation and rhizosphere microorganisms. Int J Environ Anal Chem 2005; 85:1165-74.

65. Krzysko-Lupicka T, Sudol T. Interactions between glyphosate and autochthonous soil fungi surviving in aqueous solution of glyphosate. Chemosphere 2008; 71:1386-91.

66. Meriles JM, Gil SV, Haro RJ, March GJ, Guzman CA. Glyphosate and previous crop residue effect on deleterious and beneficial soil-borne fungi from a peanut-cornsoybean rotations. J Phytopathol 2006; 15:309-16.

67. Powell JR, Swanton CJ. A critique of studies evaluating glyphosate effects on diseases associated with Fusarium spp. Weed Res 2008; 48:307-18.

68. Ronco MG, Ruscitti MF, Arango MC, Beltrano J. Glyphosate and mycorrhization induce changes in plant growth and in root morphology and architecture in pepper plants (Capsicum annuum L.). J Hortic Sci Biotechnol 2008; 497-505.

69. Holland JM. The environmental consequences of adopting conservation tillage in Europe: reviewing the evidence. Agr Ecosyst Environ 2004; 103:1-25.

70. ASA. American Soybean Association-Conservation Tillage Study. http://www.soygrowers.com/ctstudy/ ctstudy_files/frame.htm. Accessed 2008.

71. WHO. World Health Organization. Glyphosate and AMPA in Drinking-water. http://www.who.int/water_ sanitation_health/dwq/chemicals/glyphosampasum. pdf. Accessed 2008.

72. Vereecken H. Mobility and leaching of glyphosate: a review. Pest Manag Sci 2005; 61:1139-51.

73. Klier C, Grundmann S, Gayler S, Priesack E. Modelling the Environmental Fate of the Herbicide Glyphosate in Soil Lysimeters. Water Air Soil Poll 2008; 8:187-207.

74. Mamy L, Gabrielle B, Barriuso E. Measurement and modelling of glyphosate fate compared with that of herbicides replaced as a result of the introduction of glyphosate-resistant oilseed rape. Pest Manag Sci 2008; 64:262-75.

75. Scorza RPJ, Da Silva JP. Potential contamination of groundwater by pesticides in Dourados River watershed, MS-Brazil. Pesticidas 2007; 17:87-106.

76. Miller JJ, Hill BD, Chang C, Lindwall CW. Residue detections in soil and shallow groundwater after longterm herbicide applications in Southern Alberta. Can J Soil Sci 1995; 75:349-56.

77. Zablotowicz RM, Locke MA, Krutz LJ, Lerch RN, Lizotte RE, Knight SS, et al. Influence of watershed system management on herbicide concentrations in Mississippi Delta oxbow lakes. Sci Total Environ 2006; 370:552-60.

78. Shipitalo MJ, Malone RW, Owens LB. Impact of glyphosate-tolerant soybean and glufosinate-tolerant corn production on herbicide losses in surface runoff. J Environ Qual 2008; 37:401-8.

79. USGS. United States Geological Service. Pesticides in Surface and Ground Water of the United States: Summary of Results of the National Water Quality Assessment Program (NAWQA). http://water.usgs.gov/ nawqa/pnsp/. Accessed 2009.

80. Kolpin DW, Thurman EM, Linhart SM. The environmental occurrence of herbicides: The importance of degradates in ground water. Arch Environ Con Tox 1998; 35:385-90.

81. Cerdeira A, Neto C, Pinto O, Rampazzo P. Water monitoring program in a recharge area of Guarany aquifer in South America. 2003 Mississippi Water Resources Conference. Raymond, Mississippi, EUA: Mississippi Water Reserch Institute. Mississippi State University 2003. http://www.wrri.msstate.edu/publications.asp. Accessed 2009. 
82. Cerdeira AL, Desouza MD, Queiroz SCN, Ferracini VL, Bolonhezi D, Gomes MAE, et al. Leaching and half-life of the herbicide tebuthiuron on a recharge area of Guarany aquifer in sugarcane fields in Brazil. J Environ Sci Health B 2007; 42:635-9.

83. Cerdeira AL, DosSantos NAG, Pessoa MCPY, Gomes MAF, Lanchote VL. Herbicide leaching on a recharge area of the Guarany aquifer in Brazil. J Environ Sci Health B 2005; 40:159-65.

84. Lanchote VL, Bonato PS, Cerdeira AL, Santos NAG, de Carvalho D, Gomes MA. HPLC screening and GC-MS confirmation of triazine herbicides residues in drinking water from sugar cane area in Brazil. Water Air Soil Poll 2000; 118:329-37.

85. Paraiba LC, Cerdeira AL, da Silva EF, Martins JS, Coutinho HLD. Evaluation of soil temperature effect on herbicide leaching potential into groundwater in the Brazilian Cerrado. Chemosphere 2003; 53:1087-95.

86. Clark GM, Goolsby DA, Battaglin WA. Seasonal and annual load of herbicides from the Mississippi River basin to the Gulf of Mexico. Environ Sci Technol 1999; 33:981-6.

87. Meyer M, Frey JW, Lee EA, Kuivila K, Sandstrom M. Transport and degradation of glyphosate in a midwestern tile-drained watershed, Sugar Creek, Indiana. $229^{\text {th }}$ American Chemical Society National Meeting. San Diego CA, US: American Chemical Society. Washington DC, USA 2005.

88. Simonsen L, Fomsgaard IS, Svensmark B, Spliid NH Fate and availability of glyphosate and AMPA in agricultural soil. J Environ Sci Health B 2008; 43:365-75.
89. Albrechtsen HJ, Mills MS, Aamand J, Bjerg PL. Degradation of herbicides in shallow Danish aquifers: an integrated laboratory and field study. Pest Manag Sci 2001; 57:341-50.

90. Mallat E, Barceló D. Analysis and degradation study of glyphosate and of aminomethylphosphonic acid in natural waters by means of polymeric and ion-exchange solid-phase extraction columns followed by ion chromatography-post-column derivatization with fluorescence detection. J Chromatogr A 1998; 823:129-36.

91. Extoxnet. Pesticide Information Profiles http://extoxnet.orst.edu/pips/ghindex.html. Accessed 2009

92. Inoue MH, Oliveira RS Jr, Regitano JB, Tormena CA, Tornisielo VL, Constantin J. Critérios para avaliação do potencial de lixiviação dos herbicidas comercializados no Estado do Paraná. Planta Daninha 2003; 21:313-23.

93. Wauchope RD. Effects of conservation tillage on pesticide loss with water. In: Logan TJ, Davidson JM, Bake JL, Overcash MR, eds. Effects of Conservation Tillage on Groundwater Quality. Chelsea MI, USA: Lewis Publishers Inc 1987; 205-15.

94. Belluck DA, Benjamin SL, Dawson T. Groundwater Contamination by Atrazine and Its Metabolites-Risk Assessment, Policy and Legal Implications. Pesticide Transformation Products. Volume 459. Washington DC, USA: American Chemical Society 1991; 254-73.

95. Wauchope RD, Buttler TM, Hornsby AG, Augustijnbeckers PWM, Burt JP. The SCS/ARS/CES pesticide properties database for environmental decisionmaking. Rev Environ Contam T 1992; 123:1-155.
96. Gustafson DI. Groundwater ubiquity score-a simple method for assessing pesticide leachability. Environ Toxicol Chem 1989; 8:339-57.

97. Peterson RKD, Hulting ANG. A comparative ecological risk assessment for herbicides used on spring wheat: the effect of glyphosate when used within a glyphosatetolerant wheat system. Weed Sci 2004; 52:834-44.

98. Bennett R, Phipps R, Strange A, Grey P. Environmental and human health impacts of growing genetically modified herbicide-tolerant sugar beet: a life-cycle assessment. Plant Biotechnol 2004; 2:273-8.

99. Solomon KR, Thompson DG. Ecological risk assessment for aquatic organisms from over-water uses of glyphosate. J Toxicol Env Heal B 2003; 6:289-324.

100. Solomon KR, Anadon A, Carrasquilla G, Cerdeira AL, Marshall J, Sanin LH. Coca and poppy eradication in Colombia: Environmental and human health assessment of aerially applied glyphosate. Rev Environ Contam T 2007; 190:43-125.

101. Tsui MTK, Chu LM. Environmental fate and nontarget impact of glyphosate-based herbicide (Roundup (R) in a subtropical wetland. Chemosphere 2008; 71:439-46.

102. Farmer DR, Goldstein D, Mortensen S. External, nonstandard studies: What impact do they have on glyphosate's public perception? 236 $6^{\text {th }}$ American Chemical Society National Meeting. Philadelphia PA, USA: American Chemical Society. Washington DC, USA $2008 ; 72$. 